\title{
Development, Organoleptic Evaluation and Acceptability of Products Developed from Agro Based Wastes-Seeds and Rind of Watermelon
}

\author{
Amatullah Quadri*, Avanti Rao \\ Department of Nutrition and Dietetics, Madina Degree and PG College for Women, Himayathnagar, Hyderabad, \\ India
}

*Corresponding Author: Amatullah Quadri, Department of Nutrition and Dietetics, Madina Degree and PG College for Women, Himayathnagar, Hyderabad, India, E-mail: amatullahqadri@ gmail.com

Received: 08 October 2018; Accepted: 24 October 2018; Published: 14 November 2018

\begin{abstract}
The aim of the present study was to utilize, develop and evaluate value added products of agro based waste-seeds and rind of watermelon. In view of its high nutritional content, they have very good potential food value to serve as supplements in food formulations. Four products were developed (Juice, Salad, Jam and Protein bars) along with their respective variations, from which Juice and Salad were subjected only for numerical scoring whereas Jam and Protein bars were subjected to detailed hedonic scaling. Protein bars containing ragi flakes and jam made only with Watermelon rind were the most acceptable amongst the three and two respective formulations. Statistical analysis was applied and fudicial limits of the above mentioned parameters were obtained.
\end{abstract}

The scores obtained for overall acceptability were analysed using ' $t$ ' test. It was found that the calculated value (2.83) was greater than the table value (1.64) at 5\% level of significance. Hence there is no significant difference observed between the two variations of jam and in Protein bars it was found that Variation 1 (4.07) and Variation 3 (5.55) are highly significant and Variation 2 (1.65) is significant at $\%$ level significance. Thus, the present study concluded that seeds and the rind of watermelon could be successfully incorporated in jam and protein bars without affecting the sensory or nutritional quality of finished product. It can be consumed by all age groups during breakfast (jam) or snack time.

Keywords: Agro waste; Watermelon seeds; Watermelon rind 


\section{Introduction}

The most common problems in food processing is the disposal of the sub-products generated. This "waste material" produces ecological problems related to the proliferation of insects and rodents and an economic burden because of transportation to repositories. Therefore strategies for the profitable use of this material are needed. In recent times more attention has been focused to recover valuable components from neglected food parts (food "losses", "wastes", "by-products" or "wasted by-products") and recycle them inside the food chain, in an economic and sustainable way. The juice or pulp from watermelon is considered as the edible portion but rind and seeds are discarded as major solid wastes [1-2]. Watermelon seeds are known to be highly nutritional; they are rich sources of protein, B vitamins, minerals (such as magnesium, potassium, phosphorous, sodium, iron, zinc, manganese and copper) and fat among others as well as phytochemicals. The seeds of watermelons are known to have economic benefits especially in countries where cultivation is on the increase. Watermelon rind contains citrulline, a non-essential amino acid, which converts to L-arginine when eaten.

\section{Materials and Methods}

\subsection{Procurement of the raw material}

The raw materials required for the preparation of the products were procured from a supermarket named Ratnadeep at Tolichowki, Hyderabad. Watermelon and watermelon seeds were procured from a local market from Mehdipatnam, Hyderabad.

\subsection{Standardization of the recipe}

Standardization is the process where a recipe is tested number of times and found a satisfactory in quantity and yield. It is a gradual trial process. The standardization procedure was carried out by repeated trials till an acceptable recipe for the preparation of the product was obtained. The amounts were finalized by assessing the appearance, texture and taste of the variations. The finalized products were jam, juice, salad and protein bar. Amounts of all the ingredients in the formulation of different products:

\begin{tabular}{|l|l|l|l|}
\hline \multicolumn{2}{|l|}{ Variation 1 } & Variation 2 \\
\hline Watermelon seeds & $100 \mathrm{gm}$ & Watermelon seeds & $30 \mathrm{gm}$ \\
\hline Watermelon rind & $60 \mathrm{gm}$ & Watermelon rind & $100 \mathrm{gm}$ \\
\hline Sugar & $5 \mathrm{gm}$ & Sugar & $60 \mathrm{gm}$ \\
\hline Cinnamon & $5 \mathrm{ml}$ & Apple & $60 \mathrm{gm}$ \\
\hline Lemon juice & & Raspberry food color & $1 \mathrm{ml}$ \\
\hline Vanilla essence & $2.5 \mathrm{ml}$ & Vanilla essence & $2.5 \mathrm{ml}$ \\
\hline
\end{tabular}

Table 1: Product name: JAM. 


\begin{tabular}{|l|l|l|l|l|l|}
\hline \multicolumn{2}{|l|}{ Variation 1 } & \multicolumn{2}{l|}{ Variation 2 } & \multicolumn{2}{l|}{ Variation 3 } \\
\hline Watermelon seeds & $20 \mathrm{gm}$ & Watermelon seeds & $20 \mathrm{gm}$ & Watermelon seeds & $20 \mathrm{gm}$ \\
\hline Watermelon rind & $100 \mathrm{gm}$ & Watermelon rind & $100 \mathrm{gm}$ & Watermelon rind & $100 \mathrm{gm}$ \\
\hline Salt & $2 \mathrm{gm}$ & Salt & $2 \mathrm{gm}$ & Salt & $2 \mathrm{gm}$ \\
\hline Lemon juice & $5 \mathrm{ml}$ & Cumin powder & $3 \mathrm{gm}$ & Mint juice & $5 \mathrm{ml}$ \\
\hline
\end{tabular}

Table 2: Product name: JUICE.

\begin{tabular}{|l|l|l|l|l|l|}
\hline \multicolumn{2}{|l|}{ Variation 1 } & \multicolumn{2}{l|}{ Variation 2 } & \multicolumn{2}{l|}{ Variation 3 } \\
\hline Watermelon seeds & $20 \mathrm{gm}$ & Watermelon seeds & $20 \mathrm{gm}$ & Watermelon seeds & $20 \mathrm{gm}$ \\
\hline Watermelon rind & $100 \mathrm{gm}$ & Watermelon rind & $100 \mathrm{gm}$ & Watermelon rind & $100 \mathrm{gm}$ \\
\hline Curd & $25 \mathrm{gm}$ & Curd & $25 \mathrm{gm}$ & Curd & $25 \mathrm{gm}$ \\
\hline Cream & $15 \mathrm{gm}$ & Cream & $15 \mathrm{gm}$ & Cream & $15 \mathrm{gm}$ \\
\hline Sugar & $15 \mathrm{gm}$ & Sugar & $15 \mathrm{gm}$ & Sugar & $15 \mathrm{gm}$ \\
\hline Salt & $3 \mathrm{gm}$ & Salt & $3 \mathrm{gm}$ & Salt & $3 \mathrm{gm}$ \\
\hline Mustard powder & $5 \mathrm{gm}$ & Mustard powder & $5 \mathrm{gm}$ & Mustard powder & $5 \mathrm{gm}$ \\
\hline Pineapple & $100 \mathrm{gm}$ & Strawberry & $100 \mathrm{gm}$ & Papaya & $100 \mathrm{gm}$ \\
\hline
\end{tabular}

Table 3: Product name: SALAD.

\begin{tabular}{|l|l|l|l|l|l|}
\hline \multicolumn{2}{|l|}{ Variation 1 } & \multicolumn{2}{l|}{ Variation 2 } & Variation 3 \\
\hline Watermelon seeds & $5 \mathrm{gm}$ & Watermelon seeds & $5 \mathrm{gm}$ & Watermelon seeds & $5 \mathrm{gm}$ \\
\hline Watermelon rind & $5 \mathrm{gm}$ & Watermelon rind & $5 \mathrm{gm}$ & Watermelon rind & $5 \mathrm{gm}$ \\
\hline Dates & $10 \mathrm{gm}$ & Dates & $10 \mathrm{gm}$ & Dates & $10 \mathrm{gm}$ \\
\hline Ragi flakes & $20 \mathrm{gm}$ & Jowar flakes & $20 \mathrm{gm}$ & Bajra flakes & $20 \mathrm{gm}$ \\
\hline
\end{tabular}

Table 4: Product name: PROTEIN BARS. 


\section{Method of preparation}

\subsection{Jam Variation 1}

Peel the outer covering of watermelon and cut the rind into small pieces.

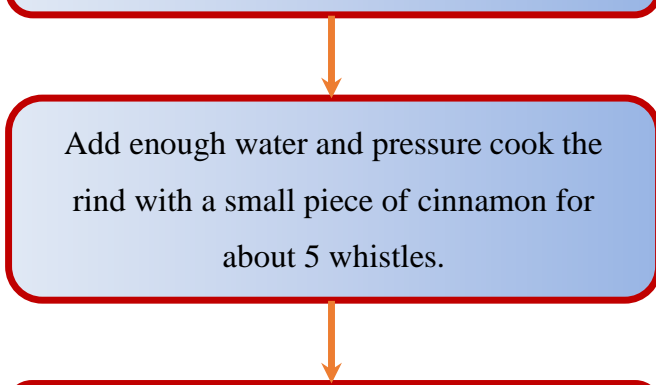

Remove the cinnamon and grind the rind to a pulp to obtain a uniform mass.

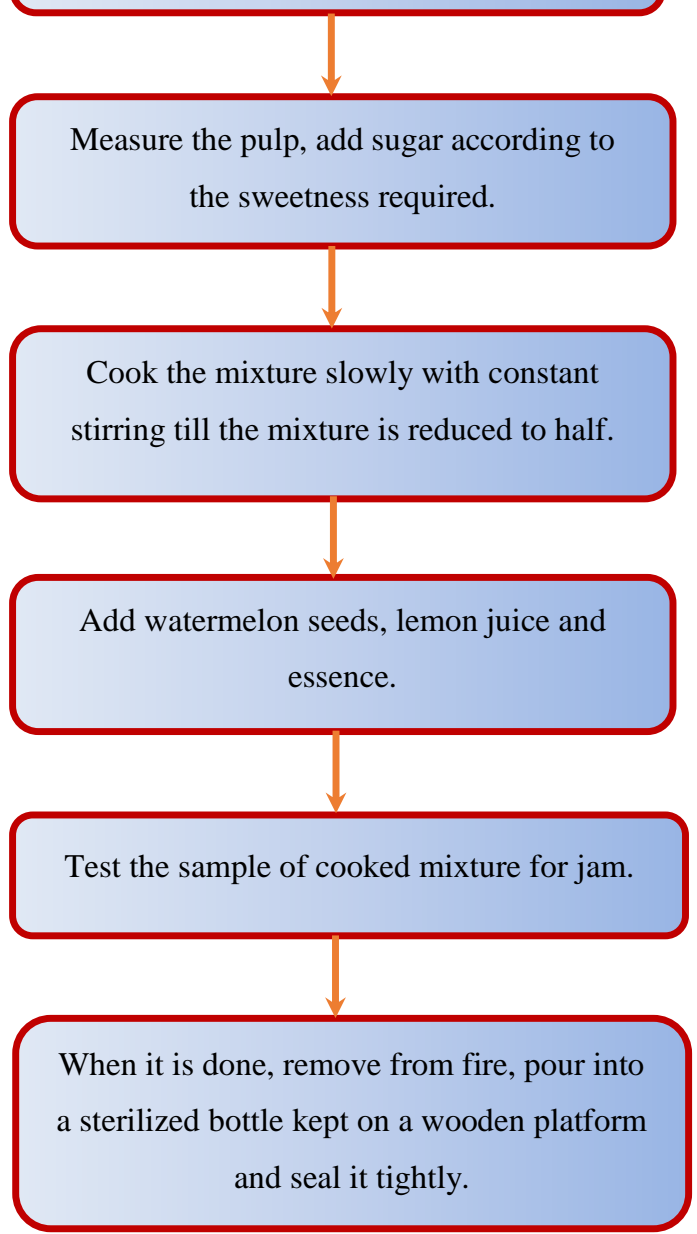

Figure 1: Flow diagram for preparation of Watermelon rind jam. 


\subsection{Variation 2 (Apple)}

Peel the outer covering of watermelon and cut the rind into small pieces.

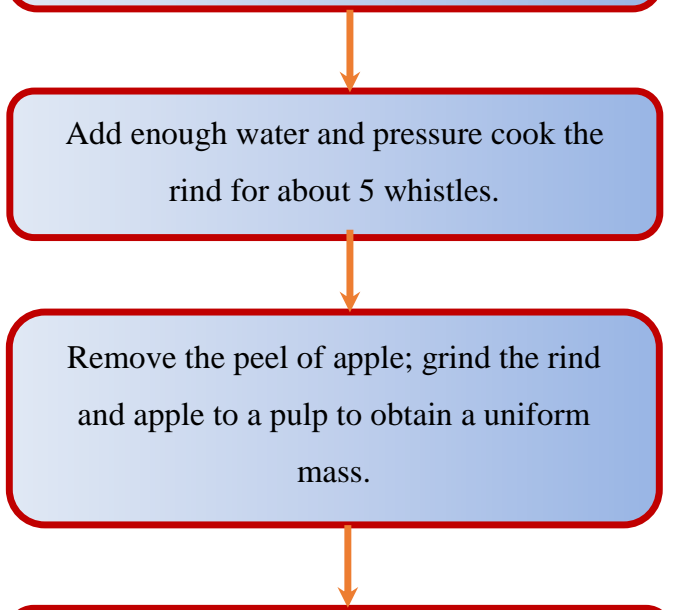

Measure the pulp, add sugar according to the sweetness required.

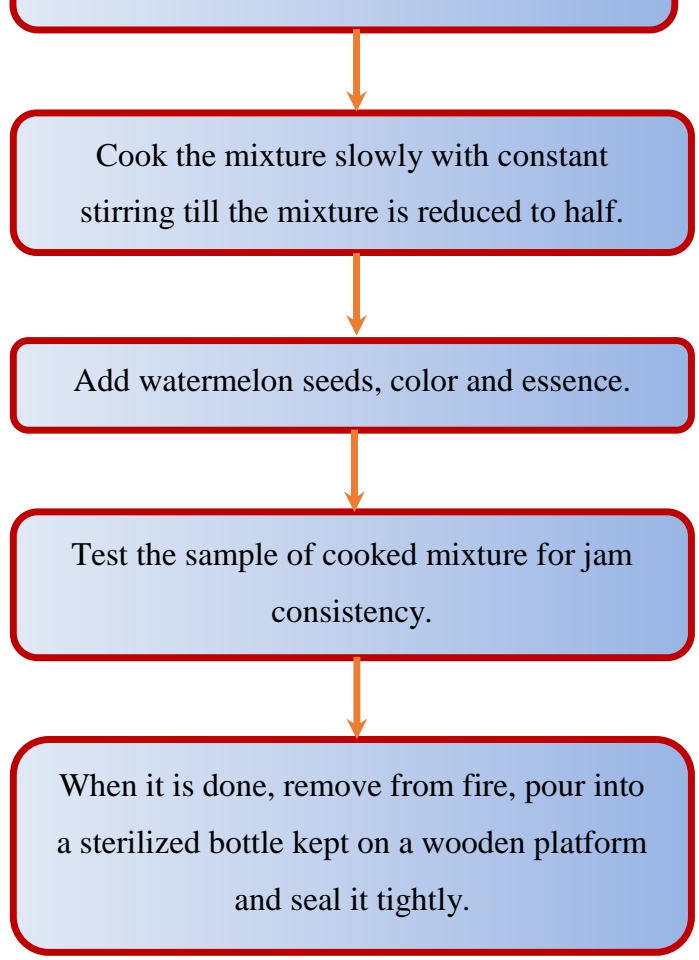

Figure 2: Flow diagram for preparation of Watermelon rind jam with apple. 


\subsection{Juice Variation 1 (Lemon juice)}

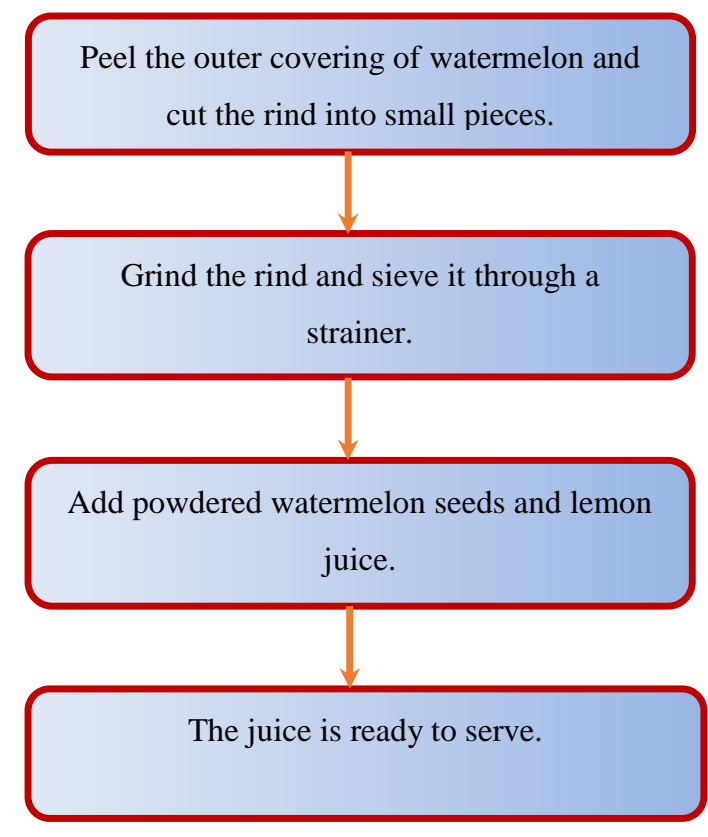

Figure 3: Flow diagram for preparation of watermelon rind juice incorporated with lemon.

Note: The method of preparation for variation 2 and variation 3 is same as variation 1 besides adding cumin powder and mint juice.

\subsection{Salad Variation 1 (Pineapple)}

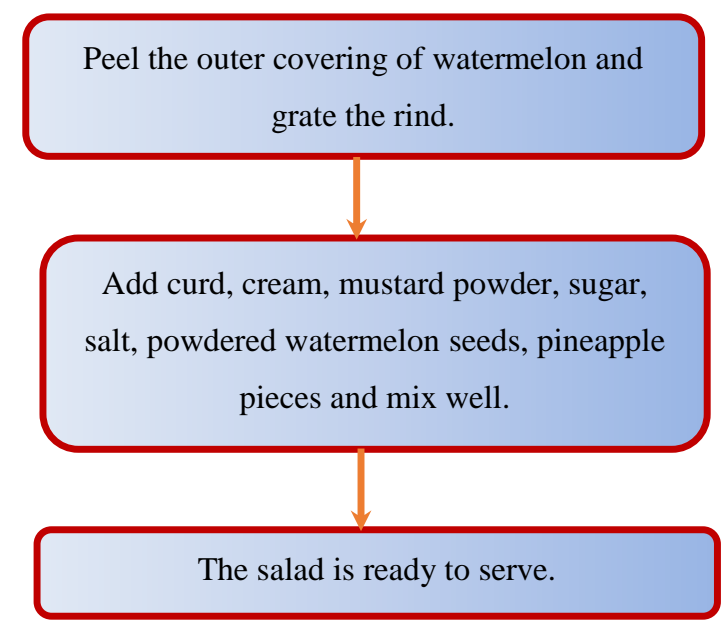

Figure 4: Flow diagram for preparation of watermelon rind salad incorporated with pineapple.

Note: The method of preparation for variation 2 and variation 3 is same as variation 1 besides adding strawberry and papaya. 


\subsection{Protein bars Variation 1 (Ragi)}

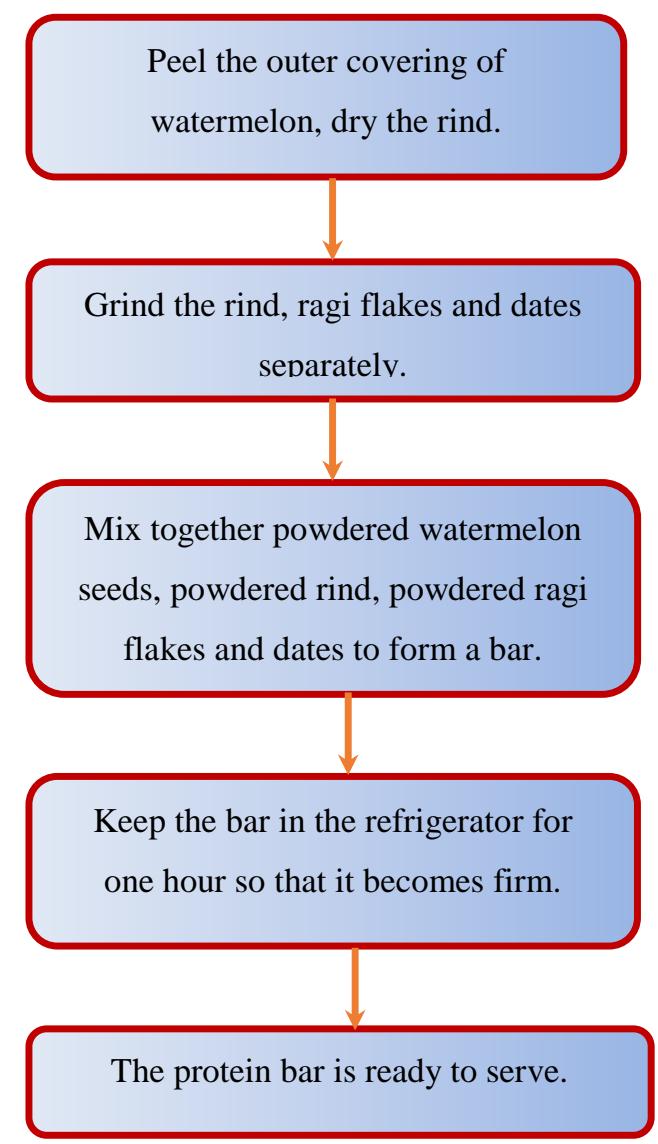

Figure 5: Flow diagram for preparation of protein bars incorporated with ragi flakes.

Note: The method of preparation for variation 2 and variation 3 is same as variation 1 besides adding jowar flakes and ragi flakes.

\subsection{Sensory evaluation of the developed products}

The sensory evaluation of the five developed samples (Jam-2; Protein bar-3) was carried out by 70 semi-trained panelists. The panelists made hedonic evaluation of the samples and were asked to assess the jam and protein bars for overall acceptability based on the color, taste and texture.

\subsection{Statistical analysis of nutrient content of the products}

Moisture Analysis was followed by Ashing. After dry ashing is done, incineration at high temperature $\left(525^{\circ} \mathrm{C}\right.$ or higher) accomplished in a muffle furnace. Estimation of mineral content such as and Iron (Fe), Calcium (Ca) were performed using titrimetric method. The iron content in protein bar with bajra flakes (Variation 3) is the highest $(0.92 \mathrm{mg} / 100 \mathrm{~g})$ and least is Variation 1 with ragi flakes $(0.61 \mathrm{mg} / 100 \mathrm{~g})$. The calcium content in protein bar with ragi flakes (Variation 1) is the highest $(88.3 \mathrm{mg} / 100 \mathrm{~g})$ and least is Variation 2 with jowar flakes $(0.61 \mathrm{mg} / 100 \mathrm{~g})$. 


\section{Results and Discussion}

It has been found that the mean scores of Jam for color of Variation 1 (7.9) was greater than Variation 2 (7.6). The flavor of Variation 2 (7.5) was greater than Variation 1 (7.3). The texture of Variation 2 (7.4) was greater than Variation 1 (7.3). The taste of Variation 2 (7.5) was greater than Variation 1 (7.3). The overall acceptability of Variation 2 (7.6) was greater than Variation 1 (7.4).

The data was analysed by using Analysis of Variance (ANOVA) test and the calculated value (0.875) was less than the table value. Hence there was no significant difference observed at $1 \%$ and $5 \%$ level of significance. The Duncan's Multiple Range test (DMRT) showed the results that Variation 2 was non-significant from Variation 1. The scores obtained for overall acceptability were analysed using ' $t$ ' test. It was found that the calculated value (2.83) was greater than the table value (1.64) at 5\% level of significance. Hence there is significant difference observed between the two variations of jam.

The mean scores of Protein bars for color of Variation 1 (8.1) was greatest followed Variation 2 (7.9) and the least acceptable was Variation 3 (7.6). The flavor of Variation 1 (8.0) was greatest followed Variation 2 (7.6) and the least acceptable was Variation 3 (7.4). The texture of Variation 1 (8.1) was greatest followed Variation 2 (7.8) and the least acceptable was Variation 3 (7.7). The taste of Variation 1 (8.0) was greatest followed Variation 2 (7.4) and the least acceptable was Variation 3 (7.2). The overall acceptability of Variation 1 (8.1) was greatest followed Variation 2 (7.5) and the least acceptable was Variation 3 (7.2).

The data was analyzed by using Analysis of Variance (ANOVA) test and the calculated value (2.18) was less than the table value. Hence there was no significant difference observed at $1 \%$ and $5 \%$ level of significance. The Duncan's Multiple Range test (DMRT) showed the results that Variation 2 (jowar flakes) was significantly different from Variation 3 (bajra flakes) whereas Variation 1 (ragi flakes) was non-significant from Variation 2 (jowar flakes). The data was analysed by ' $t$ ' test which showed that all three variations are significantly different from other $(4.07 ; 1.65 ; 5.55)$ at $5 \%$ level significance.

\section{Conclusion}

It can be concluded that Variation 2 (watermelon rind jam) of Jam and Variation 1 (ragi flakes) of Protein bars have the highest consumer acceptability. Hence, there is a significant potential for the development of value added products from watermelon seeds and rind. It's promising nutritional facts gives warranty for further studies to increase the dietary use of these food wastes and reduce the attendant burden in the environment.

\section{References}

1. Bawa As, Bains Gs. Integrated processing of watermelons for juice and seed. Indian food packer 31 (1977): 12-15.

2. Reetapa Biswas, Tiyasa Dey, Santa Dutta (De). A comprehensive review on watermelon seed-the spitted 
one. International Journal of Current Research 8 (2016): 35828-35832.

3. Agnes M Rimando, Penelope M Perkins-Veazie. Determination of citrulline in watermelon rind. Journal of Chromatography A 3 (2005): 196-200.

4. Gladvin G, Sudhaakr G, Swathi V, et al. Mineral and Vitamin Compositions Contents in Watermelon Peel (Rind). International Journal of Current Microbiology and Applied Sciences 5 (2017): 129-133.

Citation: Amatullah Quadri, Avanti Rao. Development, Organoleptic evaluation and Acceptability of Products Developed from Agro Based Wastes-Seeds and Rind of Watermelon. Journal of Food Science and Nutrition Research 1 (2018): 001-009.

(C) (1) This article is an open access article distributed under the terms and conditions of the Creative Commons Attribution (CC-BY) license 4.0 